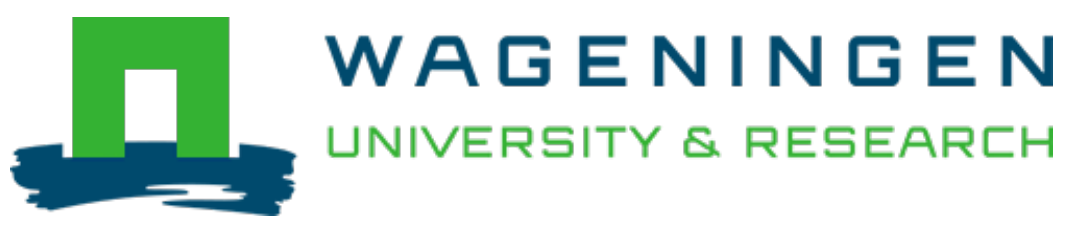

\title{
A dynamic view of seagrass meadows in the wake of successful green turtle conservation
}

\author{
Nature Ecology \& Evolution \\ Christianen, Marjolijn J.A.; Katwijk, Marieke M.; Tussenbroek, Brigitta I.; Pagès, Jordi F.; Ballorain, Katia et \\ al \\ https://doi.org/10.1038/s41559-021-01433-Z
}

This publication is made publicly available in the institutional repository of Wageningen University and Research, under the terms of article $25 \mathrm{fa}$ of the Dutch Copyright Act, also known as the Amendment Taverne. This has been done with explicit consent by the author.

Article 25 fa states that the author of a short scientific work funded either wholly or partially by Dutch public funds is entitled to make that work publicly available for no consideration following a reasonable period of time after the work was first published, provided that clear reference is made to the source of the first publication of the work.

This publication is distributed under The Association of Universities in the Netherlands (VSNU) 'Article 25fa implementation' project. In this project research outputs of researchers employed by Dutch Universities that comply with the legal requirements of Article $25 \mathrm{fa}$ of the Dutch Copyright Act are distributed online and free of cost or other barriers in institutional repositories. Research outputs are distributed six months after their first online publication in the original published version and with proper attribution to the source of the original publication.

You are permitted to download and use the publication for personal purposes. All rights remain with the author(s) and / or copyright owner(s) of this work. Any use of the publication or parts of it other than authorised under article $25 \mathrm{fa}$ of the Dutch Copyright act is prohibited. Wageningen University \& Research and the author(s) of this publication shall not be held responsible or liable for any damages resulting from your (re)use of this publication.

For questions regarding the public availability of this publication please contact openscience.library@wur.nl 


\title{
A dynamic view of seagrass meadows in the wake of successful green turtle conservation
}

\author{
Concerted conservation efforts have led to a remarkable recovery of multiple green turtle (Chelonia mydas) populations \\ worldwide. The voracious feeding of these returning populations is radically transforming tropical seagrass habitats in \\ ways that prompt a re-think of the reference state and management plans for seagrass meadows.
}

\author{
Marjolijn J. A. Christianen, Marieke M. van Katwijk, Brigitta I. van Tussenbroek, Jordi F. Pagès, \\ Katia Ballorain, Nachiket Kelkar, Rohan Arthur and Teresa Alcoverro
}

W hat was 'pristine' in the coastal oceans? An idealized concept of the pristine pervades ecological and conservation thinking, and is influenced by a forest-centred view of nature ${ }^{1}$. The (mis)conception of forests as a 'pristine' state and savannahs as 'degraded' has a marine equivalent in seagrass meadows. Meadows composed of large, slow-growing climax seagrass species are currently considered healthy, while meadows with fast-growing pioneer seagrass species are considered disturbed or in decline. This view inadvertently neglects the role that megaherbivore grazing played in the past ${ }^{1}$ and reflects a much more recent functioning of seagrass meadows, long after their principal megaherbivores (turtles and sirenians) became ecologically extinct ${ }^{2}$. Here we document the dynamic stages meadows undergo as a result of megaherbivoreseagrass interactions and propose them as a baseline against which to evaluate effective management, including prevention of meadow collapse.

Recently, green turtles (Chelonia mydas) - large-bodied marine herbivores that feed on seagrass - have seen substantial population increases following centuries of low abundance. This has resulted in locally dense aggregations of green turtles in their seagrass foraging grounds. Their dramatic impact on seagrass seascapes has been reported at five green turtle feeding grounds in the Indian Ocean, Pacific Ocean, Atlantic Ocean and the Caribbean (Fig. 1). At low turtle densities, green turtles feed on competitively dominant, long-lived seagrass, selectively foraging on nutritious young leaf tissue. As grazing increases, turtles create specific grazed areas within the meadow that they revisit and repeatedly graze, maintaining high nutrient intake (described as 'rotational grazing ${ }^{3}$ ). Grazing increases plant nutrient content $^{4}$, and although productivity may initially increase ${ }^{5}$ it declines when grazing intensifies and/or is prolonged ${ }^{3,5}$. Upon sustained grazing, rotational grazing shifts towards random grazing and seagrass pioneer species gradually replace climax species $^{3,6}$. Ultimately, pioneer shoot densities will decrease too, and turtles resort to digging up rhizomes, targeting nutritious belowground tissues ${ }^{5}$. This eventually leads to meadow collapse, triggering turtle migrations to new foraging grounds. In some cases, meadow collapse can occur even before turtles dig up the rhizome, when consumption far outweighs productivity and pioneer species do not occupy the grazed areas ${ }^{4}$. These case studies show that green turtles respond to changes in seagrass composition and abundance with extraordinary flexibility in feeding strategies that allow them to exploit new meadow resources while maintaining site-fidelity ${ }^{7}$.

This depiction of seagrass habitats in the presence of large numbers of green turtles paints a different picture of the normal functioning of tropical seagrass ecosystems to that of large uninterrupted stands of climax ecosystems. Instead, we suggest that 'pristine' seagrass meadows, with their full complement of meso- and mega- herbivores, consist of spatio-temporally dynamic mosaics in different states of grazing pressure and recovery. Meadows dominated by highly grazed, short-lived, pioneer species may exist alongside meadows of long-lived climax assemblages that have escaped grazing.

We currently value seagrass meadows for the numerous ecosystem services they provide, such as coastal protection, provision of habitat, nutrient cycling and carbon storage. Though some of these services might be unaffected under low herbivory ${ }^{8}$, and may even be enhanced under intermediate grazing, they are likely to be substantially compromised when seagrass meadows become functionally extinct due to intensified turtle grazing ${ }^{9}$. At seascape scale, in parallel with forest-savannah mosaics, a full spectrum of seagrass meadow states likely provides a higher diversity of ecosystem services than a sea fringed solely by long-lived climax meadows.

How do we reconcile this new dynamic baseline with the conservation of seagrass meadows and their functioning? For a start, it requires us to move beyond polarized conservation approaches that prioritize either turtle numbers or seagrass meadow functions. It may be necessary to accept that seagrass mosaics - characterized by a full spectrum of meadow states, from rich, fully developed meadows to sparse habitats - are not signs of a degraded seascape and, in fact, may reflect pre-Anthropocene ecosystems more closely. By embracing this more nuanced understanding, we move from the view of 'nature in balance' that still pervades literature and environmental policy ${ }^{1}$ towards appreciating the 'flux of nature', where herbivory (and disturbances in general) plays a central role. Increasing green turtle populations may lead to seagrass meadows that cycle through periods of decline and recovery worldwide. However, recovery of seagrass beds 'from scratch' is typically slow and unpredictable ${ }^{10}$. Borrowing from forest-savannah systems, this state would be the equivalent of a terrestrial 'desert'. It may be necessary to intervene in grazed meadows before imminent collapse. Measures could be taken to exclude turtles, either from small remnant patches to facilitate meadow recovery once turtles have abandoned the site or to exclude grazing, for example through (re-)introduction of calcareous free-living algae that protect basal leaf sections, meristems and roots ${ }^{11}$. These ameliorative measures take on even more urgency as seagrass habitat degradation intensifies due to human influence. In light of the degrading state of tropical seagrass meadows, we may also need to revisit active green turtle conservation efforts, involving stakeholders in both seagrass and sea turtle conservation.

Conceptions of the pristine are more value-laden than ecologically relevant. 


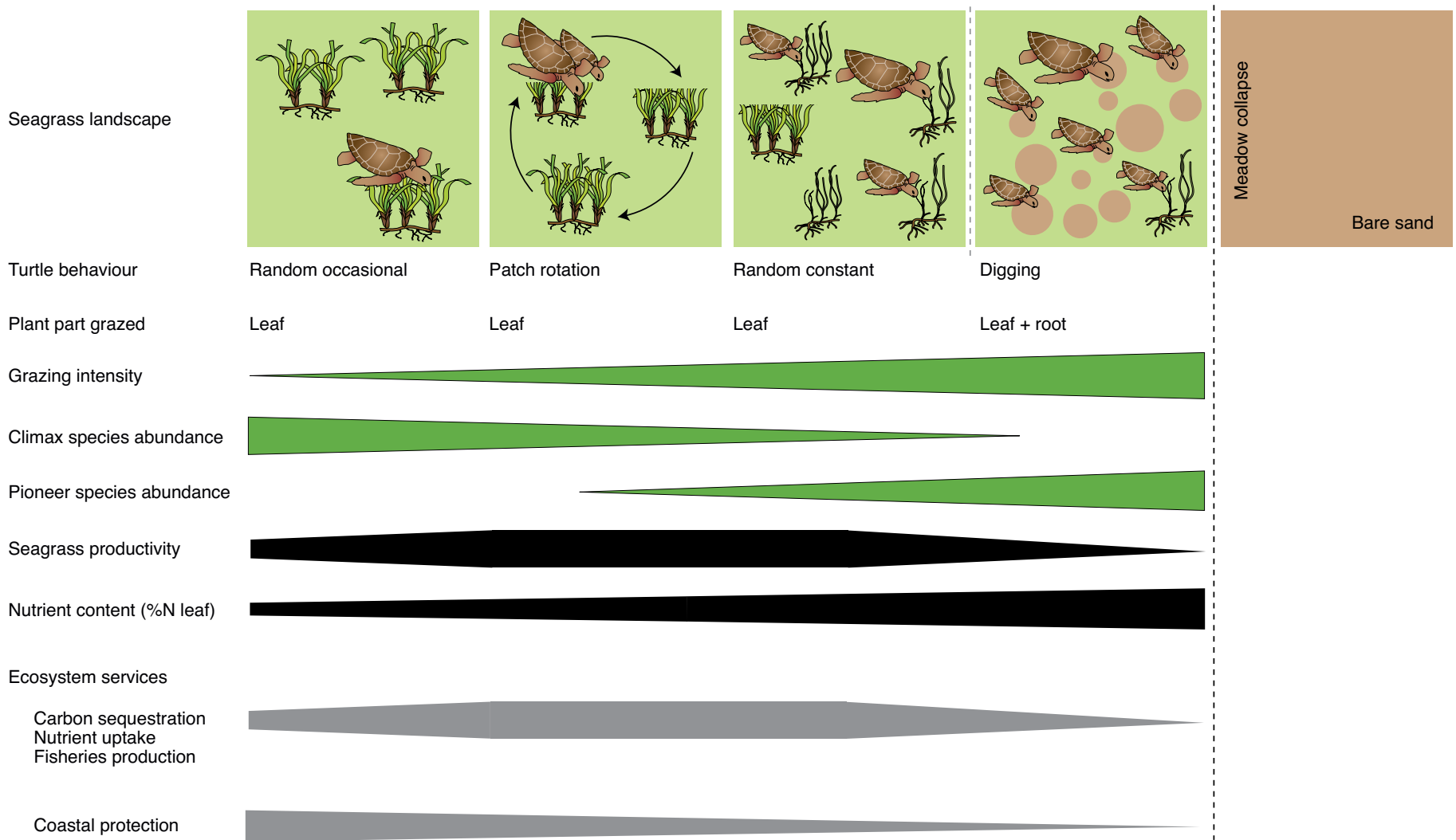

Fig. 1 | Green turtle grazing impact on seagrass seascapes. Under increased turtle densities (from left to right) and sustained turtle grazing regimes, turtles change feeding strategies to exploit new meadow resources while maintaining site fidelity. Seagrass meadows experience dramatic changes in their landscape features: tall meadows become intermitted with short-grazed patches, transforming into uniform short-grazed lawns and, upon turtle digging, even bare patches appear. Meadow collapse can occur either after intensive random leaf grazing in meadows where pioneer species are absent, depicted by the grey dashed line ${ }^{4}$, or as a result of erosion following digging, depicted by the black dashed line ${ }^{5}$. Along this grazing gradient, nutrient quality, primary production, species composition and ecosystem services change as well. In this figure, the ecosystem services carbon sequestration rate, nutrient uptake and fisheries production (adapted from ref. ${ }^{9}$ ) are estimated to have different ecosystem services trends compared to coastal protection trends (adapted from refs. ${ }^{12,3}$ ).

Rather than attempting to manage for a 'pristine' meadow in equilibrium state that might be largely incompatible with abundant megaherbivores, we call for embracing management policies that include seascapes characterized by inherently non-equilibrium dynamics, even if some of these habitats provide fewer ecosystem services. Although green turtles represent a rare conservation success at some locations, turtle populations continue to face a suite of pressures worldwide. The dramatic ecosystem impacts turtles have at these few locations should not compromise global conservation efforts. As conservation successes of ecosystem-modifying flagships continue, we may need to acknowledge that the dynamic mosaics they create, impoverished as some of them may seem, are paradoxically closer to pristine conditions than our Edenic conceptions of them ${ }^{12}$.

Marjolijn J. A. Christianen (D) 1,9凶,
Marieke M. van Katwijk (D) 2,9,

Brigitta I. van Tussenbroek (D) 3 , Jordi F. Pagès (D) 4,5, Katia Ballorain ${ }^{6}$, Nachiket Kelkar (D) 7 , Rohan Arthur (D) 5,8,10 and Teresa Alcoverro (D) $5,8,10$

${ }^{1}$ Wageningen University \& Research, Aquatic Ecology and Water Quality Management Group, Wageningen, the Netherlands. ${ }^{2}$ Department of Environmental Science, Institute for Water and Wetland Research, Radboud University, Nijmegen, the Netherlands. ${ }^{3}$ Reef Systems Unit, Instituto de Ciencias del Mar y Limnología, Universidad Nacional Autónoma de México, Puerto Morelos, Mexico. ${ }^{4}$ Departament de Biologia Evolutiva, Ecologia i Ciències Ambientals, Facultat de Biologia, Universitat de Barcelona, Barcelona, Spain. ${ }^{5}$ Centre d'Estudis Avançats de Blanes (CEAB-CSIC), Blanes, Spain. ${ }^{6}$ Centre d'Etude et de Découverte des Tortues Marines, Saint Leu, La Réunion, France. ${ }^{7}$ Ashoka Trust for Research in Ecology and the Environment (ATREE), Bangalore, ㄱ India. ${ }^{8}$ Nature Conservation Foundation, Mysore, India. ${ }^{9}$ These authors contributed equally: Marjolijn J. A. Christianen, Marieke M. van Katwijk. ${ }^{10}$ These authors jointly supervised this work: Rohan Arthur, Teresa Alcoverro.

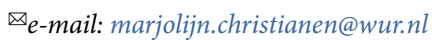

Published online: 31 March 2021

https://doi.org/10.1038/s41559-021-01433-z

\section{References}

1. Pausas, J. G. \& Bond, W. J. J. Ecol. 107, 1031-1037 (2019).

2. Bakker, E. S., Pagès, J. F., Arthur, R. \& Alcoverro, T. Ecography 39, 162-179 (2016).

3. Hernández, A. L. M. \& Van Tussenbroek, B. I. Mar. Ecol. Prog. Ser. 517, 143-157 (2014).

4. Fourqurean, J. W., Manuel, S. A., Coates, K. A., Massey, S. C. \& Kenworthy, W. J. Estuar. Coasts 42, 1524-1540 (2019).

5. Christianen, M. J. A. et al. Proc. R. Soc. B Biol. Sci. 281 20132890 (2014).

6. Kelkar, N., Arthur, R., Marba, N. \& Alcoverro, T. J. Ecol. 101, 1158-1168 (2013)

7. Shimada, T. et al. J. Anim. Ecol. 89, 1008-1016 (2020).

8. Johnson, R. A. et al. J. Ecol. 108, 1101-1114 (2020).

9. Scott, A. L. et al. Front. Plant Sci. 9, 127 (2018)

10. O’Brien, K. R. et al. Mar. Pollut. Bull. 134, 166-176 (2018).

11. Leemans, L., Martínez, I., van der Heide, T., van Katwijk, M. M. \& van Tussenbroek, B. I. Ecosystems 23, 1631-1642 (2020). 
12. James, R. K. et al. J. Ecol. 108, 2025-2037 (2020)

13. Atwood, T. B. et al. Nat. Clim. Change 5, 1038-1045 (2015).

Acknowledgements

M.J.A.C. was funded by NWO-Veni grant 181002. R.A. was funded by Rohini Nilekani Philanthropies. T.A. was supported by the project UMBRAL CTM2017-86695-C3-3R. J.F.P. was funded by the European Union's Horizon 2020 research and innovation programme under the Marie Sklodowska-Curie grant agreement no. 795315.

Author contributions

M.J.A.C., M.M.v.K., B.I.v.T., R.A. and T.A. conceptualized, visualized and wrote the Comment (original draft, review and editing). J.F.P., K.B. and N.K. contributed to writing (review and editing).
Competing interests

The authors declare no competing interests.

Additional information

Peer review information Nature Ecology \& Evolution thanks Rod Connolly and Gema Hernan for their contribution to the peer review of this work. 